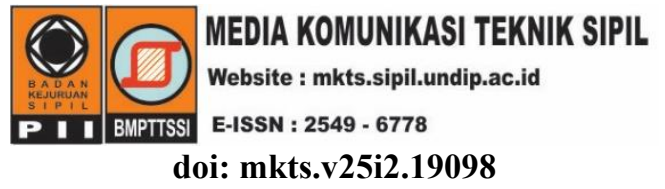

\title{
Analisis Numerik Perkerasan Sistem Pelat Terpaku Tiang Tunggal menggunakan Tiang Pipa Baja pada Tanah Lunak
}

\author{
Anas Puri \\ Program Studi Teknik Sipil, Universitas Islam Riau, Pekanbaru \\ anaspuri@eng.uir.ac.id
}

Received: 26 Mei 2018 Revised: 27 November 2019 Accepted: 3 Desember 2019

\begin{abstract}
All of the full-scale tests and numerical analysis of Nailed-slab System from previous researchers used massive reinforced concrete piles. This research will study the possibility of steel pipe pile as a replacement of massive reinforced concrete piles if there are available enough steel pipe piles. This research is aimed to study the behavior of single steel pipe pile Nailed-slab System on soft clay and the influence of pile length due to slab deflection and soil stresses. It was used the data from Puri (2015a) for a single massive reinforced concrete pile Nailed-slab. This massive reinforced concrete pile was replaced by a single steel pipe pile with similar and varied diameter which analyzed by the $2 D$ finite element method. Results show that the steel pipe pile can be used as a "nail" at the Nailed-slab pavement system but by a larger dimension compared to the massive reinforced concrete pile. The maximum effective shear stress in soil did not reach undrained shear strength under a standard wheel load $40 \mathrm{kN}$. Generally, the soil was not failure.
\end{abstract}

Keywords: Soft clay, nailed-slab system, steel pipe pile, rigid pavement

\begin{abstract}
Abstrak
Seluruh uji skala penuh dan analisis numerik sistem pelat terpaku dari berbagai peneliti terdahulu menggunakan tiang masif beton bertulang. Melalui penelitian ini akan dikaji kemungkinan penggunaan pipa baja sebagai pengganti tiang beton bertulang masif di lapangan, bilamana tersedia tiang pipa dengan jumlah cukup. Penelitian ini bertujuan untuk mempelajari perilaku sistem pelat terpaku tiang tunggal yang menggunakan tiang pipa baja pada tanah lempung lunak. Selain itu, ditinjau pula pengaruh dimensi tiang pipa terhadap perilaku lendutan dan tegangan tanah. Digunakan data penelitian Puri (2015a) untuk sistem pelat terpaku dengan tiang beton masif. Tiang beton tersebut diganti dengan tiang pipa baja berdiamater sama dan bervariasi yang dianalisis menggunakan elemen hingga 2D. Hasil penelitian menunjukkan bahwa tiang pipa baja dapat digunakan sebagai paku pada perkerasan sistem pelat terpaku, namun dengan dimensi yang lebih besar dibanding tiang beton masif. Tegangan geser efektif maksimum bekerja pada tanah tidak melampaui kuat geser undrained tanah di bawah beban roda standar $40 \mathrm{kN}$. Secara umum tanah tidak mengalami keruntuhan.
\end{abstract}

Kata kunci: Lempung lunak, sistem pelat terpaku, tiang pipa baja, perkerasan kaku

\section{Pendahuluan}

Sistem pelat terpaku dikembangkan dengan mengganti cakar berbentuk silinder sistem cakar ayam (Hardiyatmo, 2008). Cakar tersebut diganti dengan tiang pancang beton berukuran mikro.Tiang pancang yang digunakan merupakan tiang friksi dimana kapasitas dukung tiang hanya mengandalkan tahanan gesek oleh karena berada pada tanah lunak. Studi tentang sistem pelat terpaku masih terbatas pada eksperimental model di laboratorium dan uji skala penuh. Beberapa pengujian skala kecil sistem pelat terpaku pada lempung lunak telah dilakukan oleh Puri, et.al (2011a), serta uji skala penuh (skala 1:1) telah dilakukan pula seperti oleh Nasibu (2009) dan Dewi (2009) untuk pelat terpaku tiang tunggal pada lempung kaku, sedang Puri (2015a, 2015b) pada lempung lunak. Puri (2015a, 2015b) juga melakukan uji Pelat Terpaku skala penuh dengan tiga baris dan satu baris tiang pada lempung lunak dengan pembebanan tekan. Puri et al. (2015a) juga 
melakukan uji pelat terpaku skala penuh satu baris tiang pada lempung lunak dengan pembebanan cabut, serta Puri (2016) melakukan analisis numerik untuk kasus tersebut. Uji skala penuh akibat beban horizontal pada lempung lunak telah dilakukan Puri (2019). Uji model pada lempung ekspansif telah dilakukan oleh Taa (2010) dan Diana et al. (2016, 2017), serta pada gambut oleh Waruwu et al. (2017). Selain itu, juga telah dilakukan studi analisis (Hardiyatmo, 2008, 2009, dan 2011), dan analisis numerik menggunakan pendekatan Beam on Elastic Foundation (Hardiyatmo, 2011; Puri et al. 2011b; 2012a; 2012b; 2013a; 2013b; 2013c; 2015a; 2015b; Puri, 2017) serta analisis metode elemen hingga sistem pelat terpaku tiang tunggal (Dewi, 2009), dan model skala kecil pelat terpaku dengan tiga dan satu baris tiang (Puri et al. 2013a; Somantri, 2013), serta model skala penuh pelat terpaku dengan tiga baris tiang (Puri, 2015a; Puri et al. 2013d, 2014) dan 1 baris tiang (Puri, 2015a, 2015b; 2015c ;Puri et al. 2017, 2019a, 2019b). Seluruh uji skala penuh dan analisis numerik sistem pelat terpaku tersebut menggunakan tiang masif beton bertulang. Selanjutnya melalui penelitian ini akan dikaji untuk tiang berbentuk pipa baja. Hal ini mempertimbangkan kemungkinan penggunaan pipa baja sebagai pengganti tiang beton bertulang masif di lapangan, bilamana tersedia tiang pipa dengan jumlah cukup.

Penelitian ini bertujuan untuk mempelajari perilaku sistem pelat terpaku yang menggunakan tiang pipa baja. Pada penelitian ini ditinjau sistem pelat terpaku tiang tunggal pada tanah lempung lunak. Selain itu, ditinjau pula pengaruh dimensi tiang pipa terhadap perilaku lendutan dan tegangan tanah.

\section{Metode}

Penelitian ini menganalisis dengan metode elemen hingga berdasarkan model fisik yang telah dilakukan (data sekunder). Penelitian ini menggunakan data hasil uji skala penuh sistem pelat terpaku pada lempung lunak (Puri, 2015a) khusus untuk Pelat Terpaku tiang tunggal. Simulasi numerik dilakukan dengan mengganti tiang beton masif dengan tiang pipa baja. Diameter dan panjang tiang divariasikan. Bagan alir studi parametrik perkerasan sistem pelat terpaku menggunakan tiang pipa, secara keseluruhan diberikan pada Gambar 1.

Tahapan pelaksanaan penelitian dirunut sebagaimana uraian berikut. Persiapan, meliputi perizinan penelitian dll, pengumpulan data sekunder yaitu data penelitian Puri (2015a). Dilanjutkan dengan analisis data yaitu simulasi analisis lendutan pelat terpaku menggunakan metode elemen hingga (Plaxis 2D). Dalam hal ini, tiang beton masif diganti dengan tiang pipa baja. Variabel analisis berupa variasi diameter dan panjang tiang.

\section{Dimensi struktur}

Dimensi struktur pelat terpaku tiang tunggal dari Puri (2015a) diberikan pada Gambar 2. Pelat beton bertulang dengan ukuran $1,20 \mathrm{~m} \times 1,20 \mathrm{~m} \times 0,15 \mathrm{~m}$. Tiang beton masif berdiamater $0,20 \mathrm{~m}$ dan panjang $1,50 \mathrm{~m}$ tidak termasuk tebal pelat penebalan. Di bawah pelat terdapat lantai kerja setebal $0,05 \mathrm{~m}$. Adapun ukuran tiang pipa bervariasi dari ukuran $0,20 \mathrm{~m}, 0,30 \mathrm{~m}, 0,60 \mathrm{~m}$, dan 0,80m. Dimensi penampang tiang pipa diberikan pada Tabel 1 mengacu kepada dimensi yang ada di pasaran yaitu idpipe.com (2014).

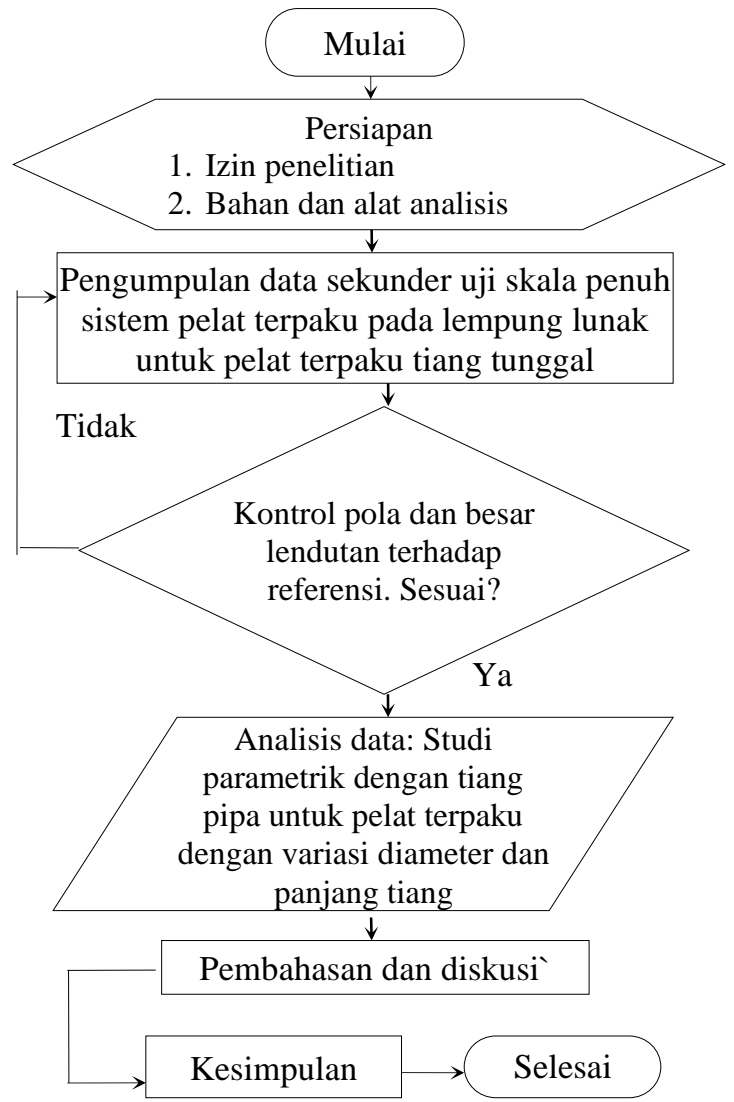

Gambar 1. Bagan alir penelitian.

Tabel 1. Tebal tiang pipa baja untuk berbagai diameter (idpipe.com, 2014)

\begin{tabular}{ccc}
\hline Diameter & \multicolumn{2}{c}{ Tebal } \\
\cline { 2 - 3 }$(\mathbf{c m})$ & $(\mathbf{m})$ & $(\mathbf{m m})$ \\
\hline $\mathrm{d}-15$ & 0,00711 & 7,11 \\
$\mathrm{~d}-20$ & 0,00818 & 8,18 \\
$\mathrm{~d}-30$ & 0,01031 & 10,31 \\
d-60 & 0,01748 & 17,48 \\
d-80 & 0,01748 & 17,48 \\
\hline
\end{tabular}




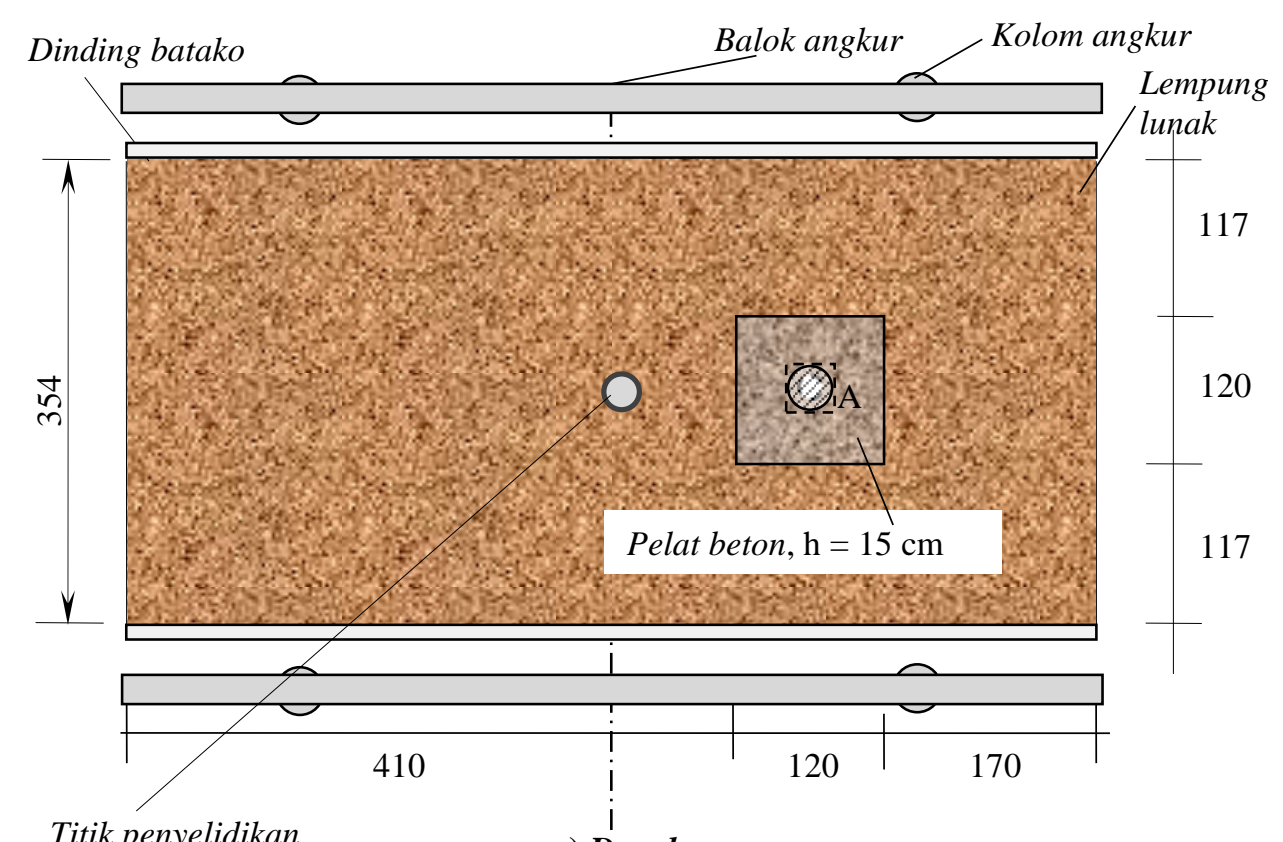
tanah

a) Denah

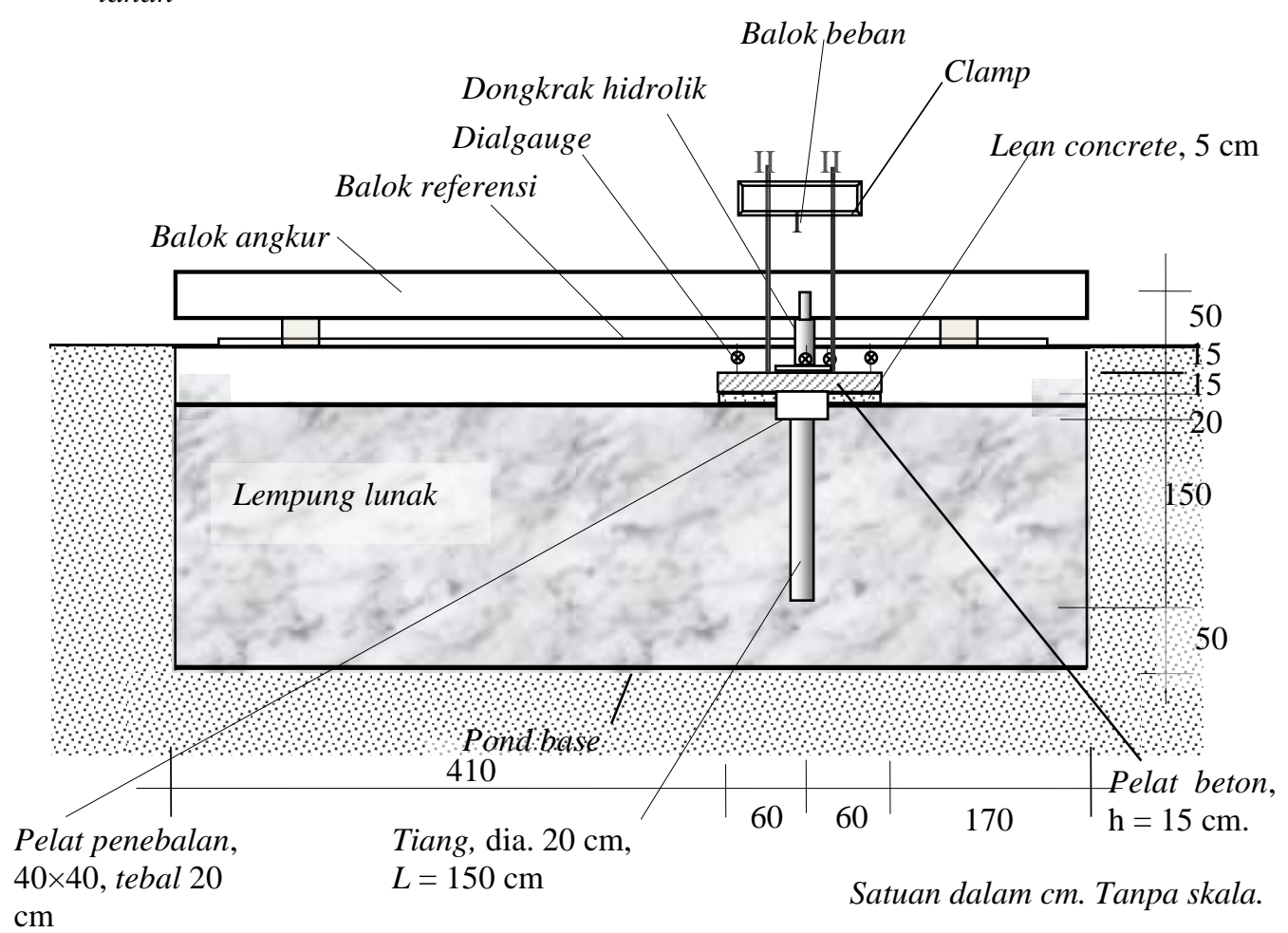

b) Potongan melintang dan peralatan pembebanan

\section{Gambar 2. Pelat terpaku tiang tunggal beton masif bertulang (Puri, 2017).}

\section{Sifat-sifat lempung lunak}

Bahan penelitian yang digunakan Puri (2015a) adalah tanah lempung lunak Ngawi-2 yang berasal dari Ngawi, Jawa Timur. Lempung ini mempunyai kadar air tanah yang cukup tinggi rerata 54,87\% dan mendekati kadar air asli 50,49\%. Berdasarkan kuat geser undrained $\left(S_{\mathrm{u}}\right)$ kondisi tidak terganggu rerata sebesar $20,14 \mathrm{kN} / \mathrm{m}^{2}$, maka termasuk kategori lunak. Kondisi lunak tersebut juga dibuktikan dengan nilai CBR lapangan rerata $0,83 \%$. Nilai $P I$ sebesar $59,98 \%$ membuat lempung ini termasuk klasifikasi $\mathrm{CH}$ (lempung plastisitas tinggi) menurut klasifikasi USCS, atau setara dengan klasifikasi A-7-6 menurut AASHTO. Distribusi ukuran butiran tanah didominasi gradasi butir halus yang mencapai rerata $92,93 \%$ dan sisanya berupa pasir halus. 


\section{Sifat-sifat beton dan baja}

Kuat tekan beton karakteristik $\left(f_{\mathrm{c}}{ }^{\prime}\right)$ sebesar 29,21 MPa untuk pelat dan 17,4 MPa untuk tiang beton. Untuk lantai kerja dengan campuran 1PC : 3PS : 5KR diasumsikan mempunyai mutu $f_{\mathrm{c}}{ }^{\prime}=14,5 \mathrm{MPa}$. Selanjutnya modulus elastisitas beton ditentukan dengan pendekatan umum sebesar $4.700 \sqrt{ } f_{\mathrm{c}}$ '. Tiang baja mempunyai modulus elastisitas 210.000 .000 $\mathrm{kN} / \mathrm{m}^{2}$.

\section{Cara analisis}

Analisis dilakukan menggunakan metode elemen hingga aksisimetri. Analisis metode elemen hingga tersebut menggunakan perangkat lunak Plaxis 2D v.8.2. Pelat dan lantai kerja dimodelkan sebagai elemen soil \& interface dengan parameter input material beton dimana model material elastik dengan perilaku non porous. Adapun tiang juga dimodelkan sebagai elemen soil \& interface namun dengan parameter input material ekivalen dari bahan pelat baja dan tanah di dalam tiang, dimana model material elastik dengan perilaku non porous. Untuk tanah menggunakan model MohrCoulomb perilaku undrained. Pelat penebalan diabaikan, namun hubungan pelat dan tiang adalah monolit. Oleh karena pelat terpaku tiang tunggal, maka tipe analisis adalah aksisimetri. Setelah dilakukan analisis path test berdasarkan dimensi penelitian Puri (2015a), diperoleh model tanah yang lebih tepat adalah model Mohr-Coulomb berperilaku undrained pada modulus elastisitas tanah $2.500 \mathrm{kN} / \mathrm{m}^{2}$ seperti ditunjukkan pada Gambar 3.

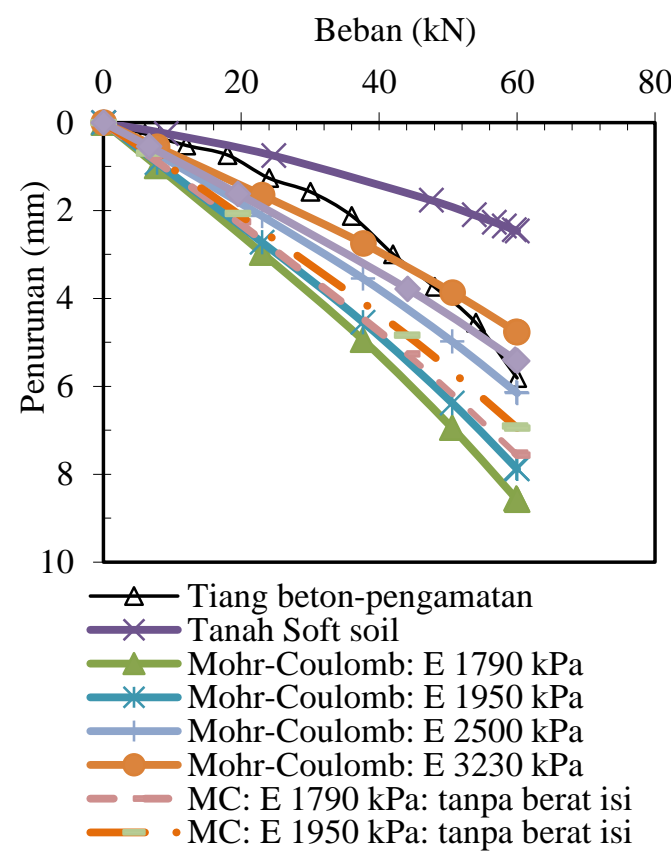

Gambar 3. Hubungan $\boldsymbol{P}$ - $\delta$ pada analisis pacth test Pelat Terpaku tiang beton tunggal.
Gambar 4 memperlihatkan deformed mesh pelat terpaku. Terlihat bahwa pelat dan tiang tidak mengalami perubahan bentuk, kecuali hanya terjadi penurunan. Permukaan pelat tetap rata dan tiang tetap vertikal yang mengindikasikan bahwa hubungan pelat dan tiang sudah monolit.

Dalam pelaksanaan pemancangan tiang pipa baja pada tanah lunak, memungkinkan tanah masuk ke dalam pipa. Maka selanjutnya dianggap tanah tersebut sebagai bagian tiang. Tiang baja mempunyai modulus elastisitas 210.000.000 $\mathrm{kN} / \mathrm{m}^{2}$ sedangkan tanah sebesar $2.500 \mathrm{kN} / \mathrm{m}^{2}$. Selanjutnya modulus tiang dan tanah tersebut diambil modulus ekivalen $\left(E_{\mathrm{eki}}\right)$ yang dihitung menggunakan Persamaan 1.

$E_{e k i}=\frac{\left(E_{S} A_{s}\right)+\left(E_{p} A_{p}\right)}{A_{t}}$

Dimana $E_{\mathrm{s}}$ : modulus elastisitas tanah $\left(\mathrm{kN} / \mathrm{m}^{2}\right)$, $A_{\mathrm{s}}$ : luas penampang tanah $\left(\mathrm{m}^{2}\right), E_{\mathrm{p}}$ : modulus elastisitas tiang $\left(\mathrm{kN} / \mathrm{m}^{2}\right), A_{\mathrm{p}}$ : luas penampang tiang $\left(\mathrm{m}^{2}\right), A_{\mathrm{t}}$ : luas penampang total pipa dan tanah $\left(\mathrm{m}^{2}\right)$. Input modulus tiang-tanah ekivalen digunakan nilai pembulatan.

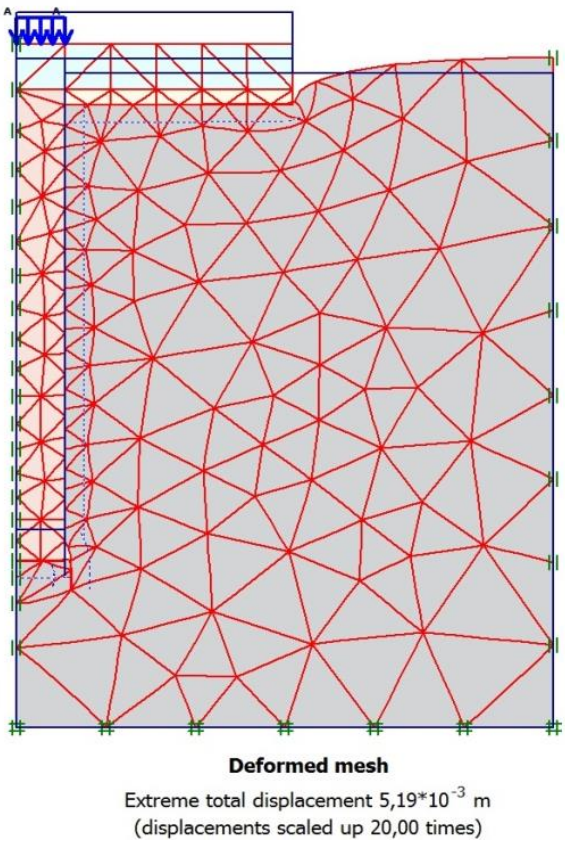

Gambar 4. Deformed mesh akibat beban sentris $40 \mathrm{kN}$ untuk tiang pipa dia. $30 \mathrm{~cm}$ dan panjang $1,50 \mathrm{~m}$.

\section{Hasil dan Pembahasan}

\section{Pengaruh diameter tiang terhadap penurunan}

Telah diuraikan pada bagian Cara Penelitian bahwa ukuran Pelat Terpaku tiang tunggal uji lapangan adalah diamater tiang $0,20 \mathrm{~m}$ dan panjang 1,50 m serta lebar pelat 1,20 m, sehingga 
dengan variasi diameter tiang yang semakin membesar maka lebar pelat yang butuhkan juga bertambah. Oleh karena diameter tiang bervariasi dari ukuran $0,20 \mathrm{~m} ; 0,30 \mathrm{~m} ; 0,60 \mathrm{~m}$; dan $0,80 \mathrm{~m}$; maka ukuran lebar pelat juga menyesuaikan dengan diameter tiang. Lebar pelat untuk diameter $0,30 \mathrm{~m}$ adalah $1,50 \mathrm{~m}$, selanjutnya untuk diamater $0,60 \mathrm{~m}$; dan $0,80 \mathrm{~m}$ masing-masing lebar pelat adalah $1,80 \mathrm{~m}$ dan $2,40 \mathrm{~m}$. Hasil terkait pengaruh diameter tiang terhadap penurunan diberikan pada Gambar 5 dan 6.

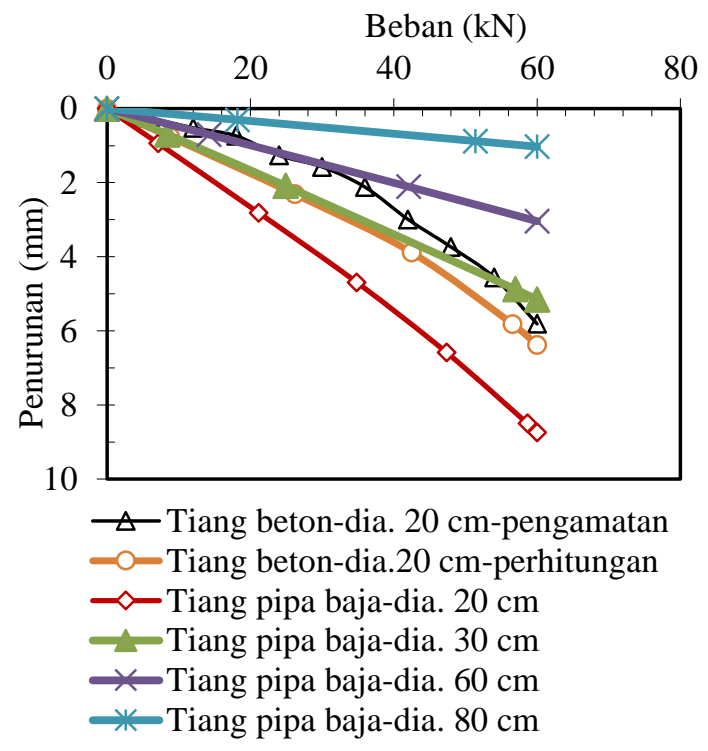

Gambar 5 . Hubungan $P$ - $\delta$ pelat untuk berbagai variasi diamater tiang untuk $L_{p}=1,5 \mathrm{~m}$.

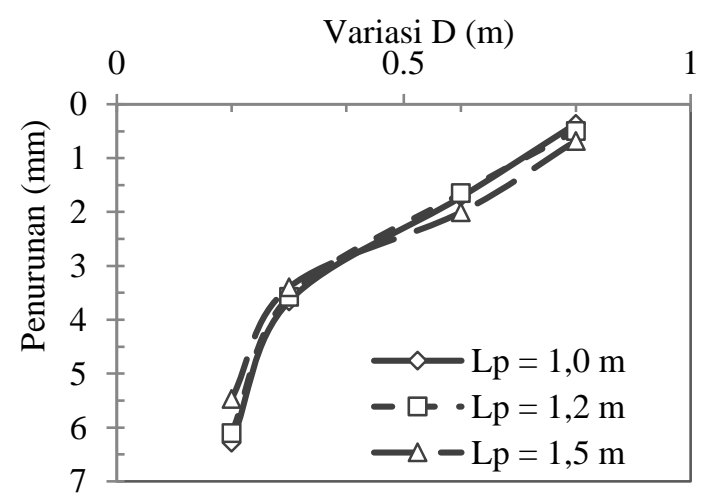

Gambar 6. Penurunan untuk berbagai diameter tiang akibat beban roda $\mathbf{4 0} \mathrm{kN}$.

Gambar 5 memperlihatkan hubungan bebanpenurunan $P-\delta$ pelat. Terlihat bahwa peningkatan diameter tiang dapat mereduksi penurunan, dalam hal ini semua tiang mempunyai panjang $1,50 \mathrm{~m}$. Untuk panjang tiang yang lainnya juga memperlihatkan perilaku yang sama. Peningkatan diameter tiang meningkatkan luas bidang kontak tanah dan selimut tiang, sehingga tahanan gesek meningkat. Hal yang sama, peningkatan diameter tiang memperbesar luas penampang ujung tiang, sehingga tahanan ujung meningkat. Namun demikian, untuk tiang yang berdiameter lebih besar dapat pula dikurangi panjangnya, tentu dengan memperhatikan bahwa penurunan masih dalam batas toleransi. Untuk seluruh diameter tiang, pada beban roda tunggal $40 \mathrm{kN}$ terlihat penurunan pelat masih di bawah penurunan maksimum izin $5 \mathrm{~mm}$ untuk berbagai panjang tiang (Gambar 6), kecuali untuk tiang pipa diameter $20 \mathrm{~cm}$ sedikit di atas penurunan maksimum izin. Diameter tiang pada rentang 30 $\mathrm{cm}-60 \mathrm{~cm}$ sudah memadai untuk digunakan dengan penurunan tidak melampaui penurunan maksimum izin.

\section{Pengaruh panjang tiang terhadap penurunan}

Gambar 7 memperlihatkan hubungan bebanpenurunan $P$ - $\delta$ pelat untuk tiang berdiameter 20 $\mathrm{cm}$. Peningkatan panjang tiang dapat mereduksi penurunan. Peningkatan panjang tiang meningkatkan luas bidang kontak tanah dan selimut tiang, sehingga tahanan gesek tiang meningkat. Untuk beban roda tunggal $40 \mathrm{kN}$ terlihat penurunan yang terjadi di atas penurunan maksimum izin $5 \mathrm{~mm}$ dengan semakin pendeknya tiang. Dengan demikian penggunaan tiang pipa dengan dimensi yang sama dengan tiang beton masif tidak aman. Hal ini disebabkan reduksi tahanan interface $\left(R_{\text {inter }}\right)$ antara baja dan tanah sebesar 0,5 lebih rendah dibanding antara tanah dan beton. Untuk meningkatkan stabilitas terhadap penurunan, dimensi tiang pipa perlu diperbesar (pada sisi panjang atau diameternya).

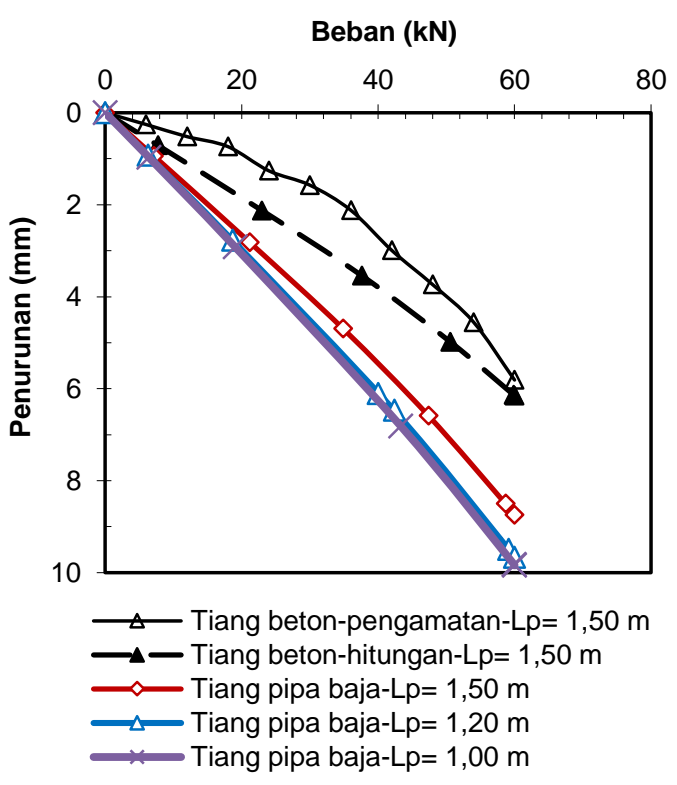

Gambar 7. Hubungan $\boldsymbol{P}-\delta$ pelat untuk variasi panjang berdiameter $20 \mathrm{~cm}$. 
Gambar 8 memperlihatkan hubungan variasi panjang tiang terhadap penurunan. Tiang berdiameter $20 \mathrm{~cm}$ tidak memenuhi syarat penurunan maksimum izin.

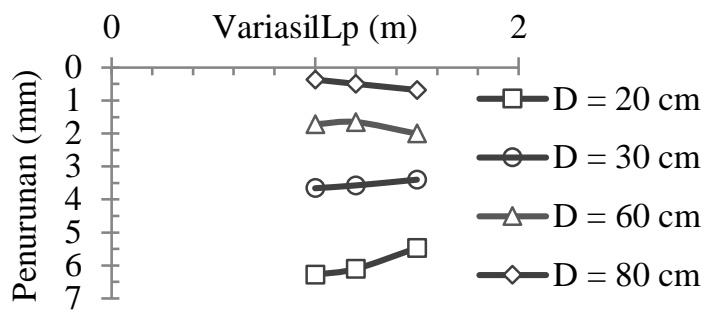

Gambar 8. Penurunan untuk berbagai panjang tiang akibat beban roda $\mathbf{4 0} \mathbf{k N}$.

Semakin panjang tiang maka penurunan cenderung semakin berkurang. Namun hal ini terjadi pada tiang dengan diameter $20 \mathrm{~cm}$ dan $30 \mathrm{~cm}$, sedangkan pada tiang yang lebih besar yaitu diameter $60 \mathrm{~cm}$ dan $80 \mathrm{~cm}$ berperilaku sebaliknya. Penurunan cenderung dengan peningkatan panjang dan diameter tiang oleh karena bertambahnya berat sendiri tiang.

\section{Tegangan dalam tanah dan perilaku bidang kontak tanah dan tiang}

Tegangan geser efektif yang berkembang pada tanah di sekitar tiang pipa diameter $20 \mathrm{~cm}$ dan panjang 1,50 m akibat beban sentris $40 \mathrm{kN}$ pada pelat terpaku tiang tunggal terlihat pada Gambar 9. Tegangan geser efektif maksimum sebesar $19,89 \mathrm{kN} / \mathrm{m}^{2}$ tidak melampaui kuat geser undrained lempung sebesar $20 \mathrm{kN} / \mathrm{m}^{2}$.

Tegangan geser tersebut bekerja di sekitar ujung bawah tiang. Secara umum tanah tidak mengalami keruntuhan. Tepat pada daerah baji di bawah ujung tiang, terjadi tegangan geser tekan. Adapun tegangan geser tarik terjadi di sepanjang tiang dan menerus sedalam $D$ di bawah dasar tiang, serta di sekitar sisi bawah tepi pelat.

Gambar 10 menyajikan tegangan geser pada bidang kontak tanah-tiang untuk tiang diameter $20 \mathrm{~cm}$ dan panjang $1,50 \mathrm{~m}$. Tegangan geser maksimum yang bekerja di bidang kontak sebesar $15,51 \mathrm{kN} / \mathrm{m}^{2}$, melampaui kondisi ultimit 10,00 $\mathrm{kN} / \mathrm{m}^{2}$ (Rintercu $\left.=0,5 \times 20\right)$. Tegangan geser meningkat dengan kedalaman dan maksimum mulai dari $0,5 L \mathrm{p}$ sampai ujung tiang (Gambar 10a). Garis putus-putus di sebelah kiri dan kanan diagram tegangan geser pada Gambar 10a adalah tahanan geser batas (limit shear resistance). Keruntuhan pada bidang kontak dibuktikan pula dengan terjadinya tension cut-off pada area tersebut seperti ditunjukkan pada Gambar 10b. Selain itu, tanah di bawah tepi pelat mengalami tegangan tarik dimana terjadi tension cut-off.

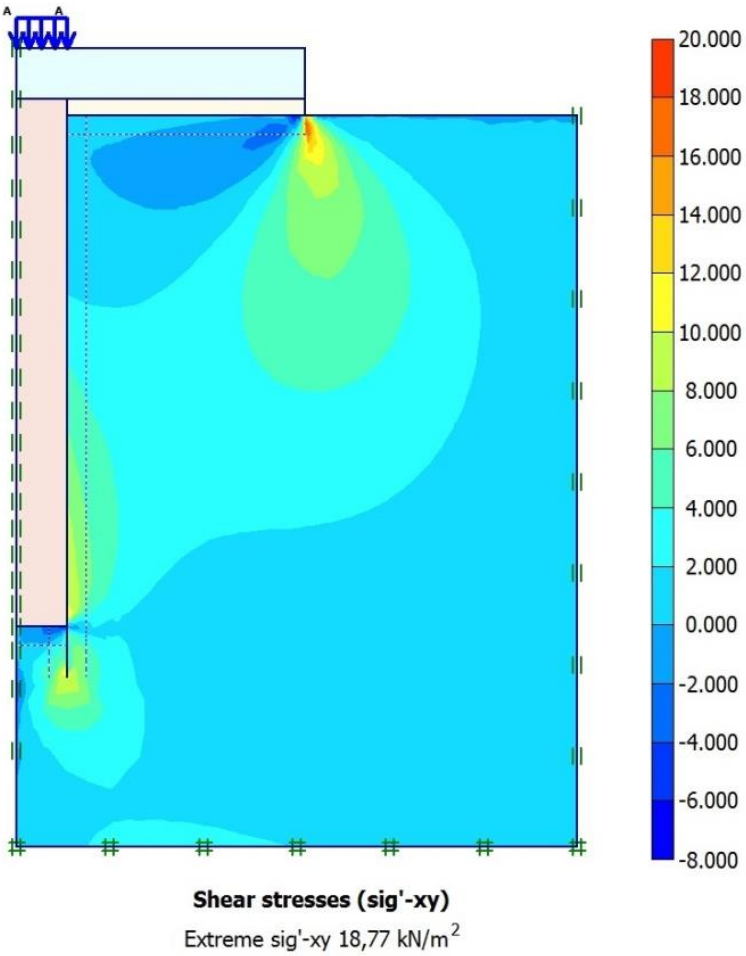

Gambar 9. Tegangan geser akibat beban sentris 40 kN untuk tiang pipa diameter $30 \mathrm{~cm}$ dan panjang $1,50 \mathrm{~m}$. 


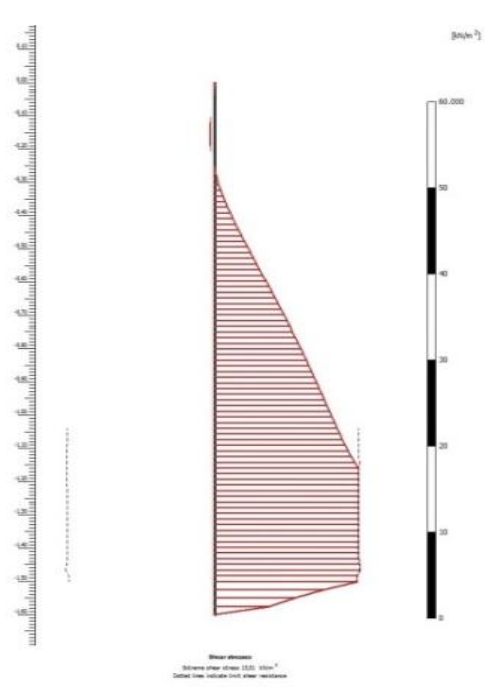

a)

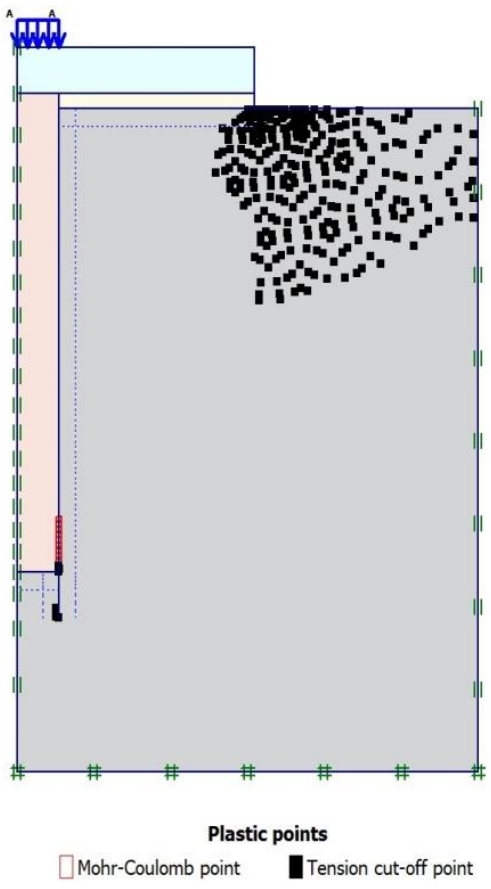

b)

Gambar 10 Perilaku bidang kontak tanah dan tiang pipa panjang 1,50 m akibat beban sentris $40 \mathrm{kN}$; a) Tegangan geser, b) Titik plastis.

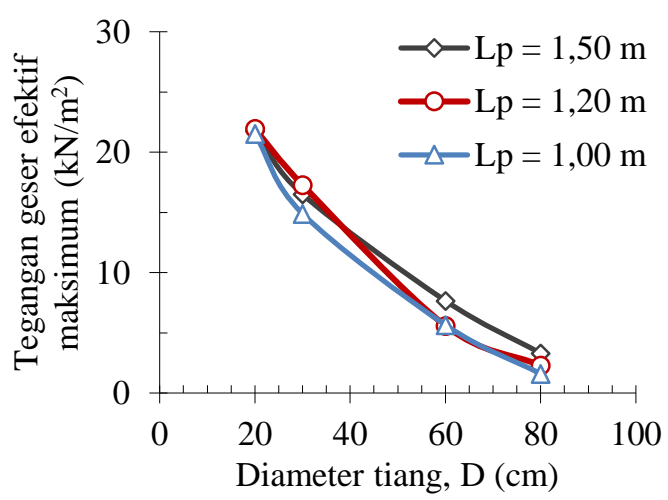

a)

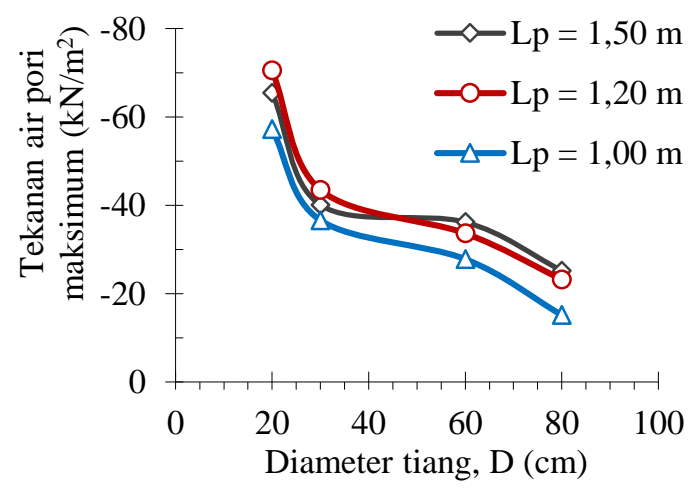

b)

Gambar 11. Tegangan dalam tanah di bawah ujung tiang, a) tegangan geser,

b) tekanan air pori.

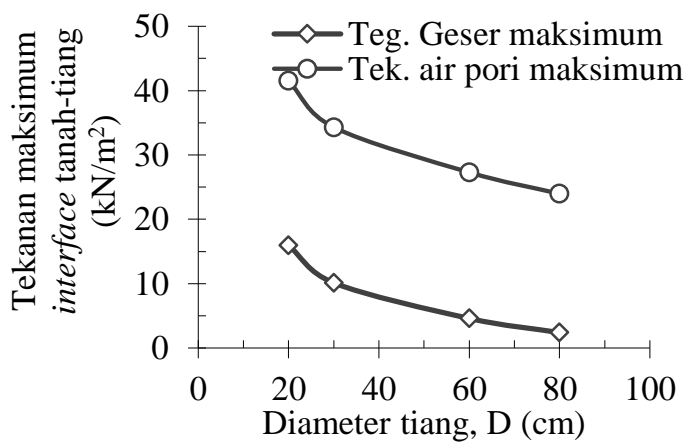

Gambar 12. Tegangan bidang kontak tanahtiang untuk $L_{p}=1,5 \mathrm{~m}$.

Gambar 11 dan 12 masing-masing memperlihatkan pengaruh dimensi tiang terhadap tegangan dalam tanah dan bidang kontak tanah-tiang. Tampak bahwa peningkatan dimensi tiang cenderung menurunkan tegangan geser (Gambar 11a) dan tekanan air pori dalam tanah (Gambar 11b) serta juga tegangan geser dan tekanan air pori pada bidang kontak tanah-tiang (Gambar 12). Demikian, struktur pelat terpaku semakin stabil dengan semakin besar dimensi tiang. Mulai dari tiang berdiameter $30 \mathrm{~cm}$, tegangan geser tidak melampaui kuat geser tanah. Dengan demikian sistem pelat terpaku ini semakin aman dengan semakin besarnya diameter tiang. Hal ini juga dibuktikan dengan menurunnya tekanan air pori sebagaimana ditunjukkan pada Gambar 11 b dan 12 tersebut. 


\section{Kesimpulan}

Berdasarkan pembahasan yang telah dilakukan, dapat disimpulkan bahwa tiang pipa baja dapat digunakan sebagai paku pada perkerasan sistem pelat terpaku, namun dengan dimensi yang lebih besar dibanding tiang beton masif. Peningkatan diameter dan panjang tiang dapat mereduksi penurunan pelat perkerasan, dimana penurunan pelat pada beban roda $40 \mathrm{kN}$ masih di bawah penurunan maksimum izin $5 \mathrm{~mm}$. Tegangan geser efektif maksimum bekerja pada tanah tidak melampaui kuat geser undrained tanah di bawah beban roda standar $40 \mathrm{kN}$. Secara umum tanah tidak mengalami keruntuhan. Peningkatan diameter dan panjang tiang dapat mereduksi tegangan geser efektif dan tekanan air pori tanah dan bidang kontak tanah-tiang. Mengacu ke perubahan tekanan air pori ini, penggunaan diameter tiang pipa antara $30 \mathrm{~cm}$ sampai dengan $60 \mathrm{~cm}$ sudah memadai dengan panjang tiang $1,20 \mathrm{~m}$.

\section{Ucapan Terima Kasih}

Penulis menyampaikan ucapan terima kasih atas dukungan finansial dari Lembaga Penelitian dan Pengabdian Masyarakat (LPPM) Universitas Islam Riau (UIR) dengan nomor kontrak 150/KONTRAK/LP-UIR/12-2015 serta saudara Muhammad Toyeb, S.T., M.T. sebagai operator komputer. Bagian analisis tiang pipa baja diameter $20 \mathrm{~cm}$ telah dipresentasikan pada Seminar Nasional Pascasarjana yang diselenggarakan oleh Departemen Teknik Sipil Universitas Indonesia pada 7 Mei 2018.

\section{Daftar Pustaka}

Dewi, D. A. (2009). Kajian Pengaruh Tiang Tunggal Terhadap Nilai Koefisien Reaksi Subgrade Ekivalen pada Uji Beban Statis Skala Penuh. Doctoral dissertation, Universitas Gadjah Mada.

Diana, W., Hardiyatmo, H. C., \& Suhendro, B. (2016, July). Small-scale Experimental Investigation on The Behaviour of Nailed Slab System in Expansive Soil. Presented at AIP Conference Proceedings (Vol. 1755, No. 1, p. 060002). AIP Publishing.

Diana, W., Hardiyatmo, H. C., \& Suhendro, B. (2017). Effect of Pile Connections on The Performance of the Nailed Slab System on The Expansive Soil. International Journal of Geomate, 12(2), 134-141.Hardiyatmo, H. C. (2008), Sistem "Pelat Terpaku" (Nailed Slab) Untuk Perkuatan Pelat Beton pada Perkerasan Kaku (Rigid
Pavement), dipresentasikan pada Prosiding Seminar Nasional Teknologi Tepat Guna dalam Penanganan Sarana-prasarana (pp. M-1-M-7), Yogyakarta, Indonesia: Jurusan Teknik Sipil dan Perencanaan, Universitas Gadjah Mada.

Hardiyatmo, H. C. (2009). Metoda Hitungan Lendutan Pelat dengan Menggunakan Modulus Reaksi Tanah Dasar Ekivalen untuk Struktur Pelat Fleksibel, Dinamika Teknik, 9 (2) 149-154.

Hardiyatmo, H. C. (2010). Perancangan sistem cakar ayam modifikasi untuk perkerasan jalan raya, Gadjah Mada University Press, Yogyakarta.

Hardiyatmo, H. C. (2011). Method to Analyze The Deflection of the Nailed-slab system. International Journal of Civil \& Environmental Engineering, 11(4), 22-28.

Hardiyatmo, H. C, Suhendro, B. (2003). Fondasi tiang dengan pile cap tipis sebagai alternatif untuk mengatasi problem penurunan bangunan di atas tanah lunak, Laporan Komprehensif Penelitian Hibah Bersaing IX Perguruan Tinggi, Lembaga Penelitian Universitas Gadjah Mada, Yogyakarta.

Nasibu, R. (2009), Kajian Modulus Reaksi Tanah Dasar akibat Pengaruh Tiang (Uji Beban pada Skala Penuh, Tesis, Universitas Gadjah Mada.

Puri, A. (2015a). Perilaku Perkerasan sistem pelat terpaku pada Lempung Lunak, Disertasi, Indonesia: Universitas Gadjah Mada.

Puri, A. (2015b). Validasi Metode Analisis Lendutan Perkerasan Sistem Pelat Terpaku pada Model Skala Penuh dengan Satu Baris Tiang, Dipresentasikan pada Prosiding PIT XIX dan KOGEI X (453-464) Jakarta, Indonesia: Himpunana Ahli Teknik Tanah Indonesia.

Puri, A. (2015c). Studi Paramterik Perkerasan sistem pelat terpaku Pada Tanah Dasar Lunak, dipresetasikan pada Proc. 1st Annual Civil Engineering Seminar (ACES) (305-313), Pekanbaru, Indonesia: Jurusan Teknik Sipil, Universitas Riau.

Puri, A. (2016). Behavior of Uplift Resistance of Single Pile Row Nailed-slab Pavement System on Soft Clay Sub Grade, dipresetasikan pada Proc. The 3rd Asia Future Conference (AFC) (12261230), Kitakyushu, Japan: Sekiguchi Global Research Association, Atsumi International Foundation.

Puri, A. (2017). Developing The Curve of Displacement Factor for Determination The 
Additional Modulus of Sub Grade Reaction on Nailed-Slab Pavement System, International Journal of Technology (IJTech), 8 (1) 122-131.

Puri, A., Hardiyatmo, C. H., Suhendro, B., \& Rifa'i, A. (2011a). Studi Eksperimental Lendutan Pelat yang Diperkuat Tiang-tiang Friksi Pendek pada Lempung Lunak, dipresentasikan pada Pertemuan Ilmiah Tahunan XIV (317-321). Yogyakarta.

Puri, A., Hardiyatmo, H. C., Suhendro, B., \& Rifa'i, A. (2011b). Kontribusi Koperan dalam Mereduksi Lendutan sistem pelat terpaku pada Lempung Lunak. Dipresentasikan pada Prosiding Konferensi Geoteknik Indonesia ke-9 dan Pertemuan Ilmiah Tahunan ke-15 (KOGEI IX \& PIT XV) HATTI, 299-306.

Puri, A., Hardiyatmo, H. C., Suhendro, B., \& Rifa'i, A. (2012a). Determining Additional Modulus of Subgrade Reaction Based on Tolerable Settlement for the Nailed-slab System Resting on Soft Clay. International Journal of Civil and Environmental Engineering IJCEE-IJENS, 12(03), 32-40.

Puri, A., Hardiyatmo, H. C., Suhendro, B., \& Rifa'i, A. (2012b). Application of the Additional Modulus of Subgrade Reaction to Predict The Deflection of Nailed-slab System Resting on Soft Clay Due to Repetitive Loadings, presented at 16th Annual Scientific Meeting (PIT) HATTI(217-222).

Puri, A., Hardiyatmo, H. C., Suhendro, B., \& Rifa'i, A. (2013a). Pile Spacing and Length Effects Due to the Additional Modulus of Subgrade Reaction of the Nailed-Slab System on the Soft Clay, presented at $13^{\text {th }}$ International Symposium on Quality in Research (QiR) (1032-1310).

Puri, A., Hardiyatmo, H. C., Suhendro, B., \& Rifa'i, A. (2013b). Deflection Analysis of Nailedslab System which Reinforced by Vertical Wall Barrier under Repetitive Loading, presented at the 6th Civil Engineering Conference in Asian Region (CECAR6), Jakarta, Indonesia: Asian Civil Engineering Consulting Council (ACECC), TS610 - TS6-11.

Puri, A., Hardiyatmo, H. C., Suhendro, B., \& Rifa'i, A. (2013c). Application of Method of Nailed-Slab Deflection Analysis on Full Scale Model and Comparison to Loading Test, presented at the 7th National Conference of Civil Engineering (KoNTekS7), G201-G211.
Puri, A., Hardiyatmo, H. C., Suhendro, B., \& Rifa'i, A. (2013d). Behavior of Fullscale NailedSlab System with Variation on Load Positions, presented at the 1st International Conference on Infrastructures Development (ICID), 26-36.

Puri, A., Hardiyatmo, H. C., Suhendro, B., \& Rifa'i, A. (2014). Behavior of Nailed-slab System on Soft Clay Due to Repetitive Loadings by Conducting Full Scale Test, presented at $17^{\text {th }}$ Intrntl. Symp. FSTPT, University of Jember, 739750 .

Puri, A., Hardiyatmo, H. C., Suhendro, B., \& Rifa'i, A. (2015a). Pull out Test of Single Pile Row Nailed-Slab System on Soft Clay, presented at The 14th International Conference on Quality in Research (QiR), Universitas Indonesia, Lombok, 63-68

Puri, A., Hardiyatmo, H. C., Suhendro, B., Rifa'i, A., \& Khatib, A. (2015b). Validasi Metode Analisis Lendutan Perkerasan Sistem Pelat Terpaku pada Model Skala Penuh dengan Satu Baris Tiang, dipresentasikan pada PIT XIX dan KOGEI X, HATTI, 453-464.

Puri, A., Suhendro, B., \& Rifa'i, A. (2017). Effects of Vertical Wall Barrier on the Rigid Pavement Deflection of Full Scale 1-Pile Row Nailed-Slab System on Soft Sub Grade. International Journal of Geomate, 12(32), 25-29.

Somantri, A. K. (2013). Kajian Lendutan Sistem Pelat Terpaku pada Tanah Pasir dengan Menggunakan Metode Beam on Elastic Foundations (Boef) dan Metode Elemen Hingga. Tesis, Universitas Gadjah Mada.

Taa, P. D. S. (2010). Pengaruh Pemasangan Kelompok Tiang terhadap Kenaikan Pelat dalam Sistem Nailed-Slab yang Terletak di Atas Tanah Dasar Ekspansif. Tesis, Indonesia: Universitas Gadjah Mada.

Waruwu, A., Hardiyatmo, H. C., \& Rifa'i, A. (2017). Behaviour of Nailed-slab Syatem on Peat Soil Under Loading, presented at the 1st Warmadewa International Conference on Architecture and Civil Engineering (91-97), Denpasar, Indonesia: Jurusan Teknik Sipil, Universitas Warmadewa. 